\title{
РАЗВИТИЕ ИДЕЙ ПРОЕКТИРОВАНИЯ КАК СПОСОБА ИННОВАЦИОННЫХ ИЗМЕНЕНИЙ В ОБРАЗОВАТЕЛЬНОЙ ОРГАНИЗАЦИИ
}

\author{
Л.И. Башкирова \\ Западнодвинский технологический колледж им. И. А. Ковалёва
}

\begin{abstract}
Аннотация: Анализ развития идей проектной деятельности в образовании убедительно показывает, что она формировалась и до настоящего времени остаётся универсальным способом постановки и решения актуальных проблем образовательной организации.
\end{abstract}

Ключевые слова: проектирование, проектная деятельность, педагогический проект, образовательный проект

\section{DEVELOPMENT OF DESIGN IDEAS AS A METHOD INNOVATIVE CHANGES IN THE EDUCATIONAL ORGANIZATION}

\author{
L.I. Bashkirova \\ Zapadnodvinsk technological College named after I. A. Kovalev
}

\begin{abstract}
The analysis of the development of ideas of project activity in education clearly shows that it was formed and still remains a universal way of setting and solving actual problems of an educational organization.
\end{abstract}

Keywords: design, project activity, pedagogical project, educational project

Современные образовательные организации переживают период качественных преобразований в содержании и организации; правовых, организационных и экономических основах их деятельности. В этой связи актуальным является анализ эволюции и современного состояния исследований проектной деятельности как универсального способа инновационных изменений в образовании. Изучение и развитие представлений о проектировании в образовании - это объективная потребность, для удовлетворения которой имеются все основания, начиная с опыта переноса в педагогику идей и практики проектирования из других областей науки и деятельности человека до формирования целостной теории проектирования в педагогической науке.

Первоначально в педагогике использовались идеи архитектурного, а затем инженерного проектирования, которые, по мнению В.Ф. Сидоренко составили основу классического проектирования, формирующегося с XVII-XVIII вв. и до XIX в. (Сидоренко, 1985: 94-96). В его рамках проектная деятельность осуществлялась на основе сложившихся норм, традиций, канонов, последовательно осуществляемых действий, обязательное следование которым должно было обеспечивать достижение поставленных перед разработчиками проектов целей. Скорее всего, именно эти идеи оказали влияние на поиски в педагогике, начиная 
с Я.А. Коменского, универсального метода, который сам основоположник педагогической науки назвал «механистическим» для человеческого образования.

В отечественной педагогической науке и практике термины «проект» и «проектирование» использовались в первой трети и практически не употреблялись во второй трети прошлого века. Первые попытки обоснования необходимости выделения проектировочного компонента в структуре деятельности педагога предприняла в середине XX в. Н.В. Кузьмина, а В.В. Краевский предложил рассматривать педагогический проект в качестве важного звена обеспечения взаимосвязи педагогической теории и практики. Более убедительно и развёрнуто Н.В. Кузьмина и В.В. Краевский изложили свои идеи в работах 80-90-х гг. Так, В.В. Краевский показал, что в системе связи педагогической науки и практики проект выступает в качестве конечного результата реализации конструктивно-технической функции педагогической науки. Он представляет собой конкретизированную модель педагогической деятельности, которая апробирована в ходе опытной работы и содержит научно обоснованные, вполне конкретные указания к деятельности учителя и ученика. Таким образом, проект в педагогике, с точки зрения В.В. Краевского, носит нормативный характер для педагогической практики (Краевский, 1994: $58-59)$.

В 80-90-е гг. XX в. началось более активное изучение проектирования как педагогической технологии и как проектировочного компонента, объективно присущего деятельности педагога и связанного с реализацией определённого алгоритма организации учебно-воспитательного процесса. В эти же годы в педагогику были перенесены идеи системного проектирования (Г.П. Щедровицкий, Н.Г. Алексеев, В.М. Розин и др.). В работах Г.П. Щедровицкого концепция педагогического проектирования и деятельности педагога-проектировщика основывалась на представлении о «тотальности проектирования», которое в 80-х90-х гг. получило обоснование в работах Ю.В. Громыко, К.М. Кантора, В.М. Розина, В.Ф. Сидоренко, Г.П. Щедровицкого.

В 90-е гг. прошлого века в Институте педагогических инноваций РАО, возглавляемом В.И. Слободчиковым, сформировалась конщепџия проектирования как самостоятельного типа деятельности, осуществляемого при разномасштабном реформировании образовательных систем (Н.Г. Алексеев, В.К. Зарецкий, С.И. Краснов, Н.Н. Михайлов, В.К. Рябцев, И.С. Якиманская и др.). Н.Г. Алексеев и В.И. Слободчиков обосновали определение проектирования как «деятельности, синтезирующей в себе два процесса: промысливание того, что должно быть, и одновременно с этим - развёртывание процессов реализации. Первый, - с их точки зрения, - подчёркивает идеальный характер действий и его нацеленность на проявление (образование) чего-то в будущем. Второй - развёртывание взаимосвязанных процессов идеального промысливания и реализации - показывает, что эта деятельность основывается на реальных, имеющих место процессах и связана с переходом от наличной ситуации к ситуации желаемого будущего» (Слобод- 
чиков, 1996: 5). При этом В.И. Слободчиков рассматривал проектирование как высшую форму инновачионной деятельности в образовательном учреждении. В последнее десятилетие прошлого века в Российском государственном педагогическом университете им. А.И. Герцена под руководством А. П. Тряпицыной были осуществлены комплексные исследования проблем педагогического проектирования.

В формировании теоретического фундамента педагогического проектирования существенный вклад внесли диссертационные исследования 90-х гг. ХХ в., предметом которых стало системное педагогическое проектирование (В.Е. Радионов), психолого-педагогическое проектирование (В.И. Слободчиков), социально-педагогическое проектирование (В.З. Юсупов), обучение педагогическому проектированию (Е.С. Заир-Бек), содержание проектирования антропоориентированного процесса (М.Н. Невзоров), особенности проектирования личностно-ориентированного обучения (Н.А. Алексеев) и др. Предметом кандидатских диссертаций стали исследования проблем проектирования отдельных объектов и предметов сферы образования (образовательных систем различного вида, образовательной среды, образовательных технологий и т.д.); обучения проектной деятельности в системе основного и дополнительного образования; организации проектной деятельности различных категорий обучающихся (С.Б. Башмакова, О.Г. Важнова, Ю.А. Гончарова, И.А. Крестинина, Т.В. Сафронова, А.И. Степанова, Е.А. Крюкова и др.).

В конце XX в. и начале XXI в. вышли коллективные работы под редакцией В.И. Загвязинского, А.М. Моисеева, В.И. Слободчикова, А.П. Тряпицыной, которые значительно расширяли предметное поле исследований проектирования в сфере образования. Для обучения студентов и слушателей курсов повышения квалификации педагогических работников образовательных учреждений были изданы учебники и учебные пособия В.С. Безруковой, А.И. Богданова, М.П. Горчаковой-Сибирской, Ю.В. Громыко, И.А. Колесниковой, М.И. Рожкова, В.З. Юсупова и др. В результате проведённых исследований и обобщения передовой образовательной практики в педагогической науке сложилось достаточно целостное представление о роли и месте проектирования в системе педагогического знания. И о проектировании, как способе инновационных изменений в образовательной организации, о его теоретических основах и логике, видах проектов в образовании и т.д.

В современной педагогической науке в качестве «собирательных» используются два термина «педагогическое проектирование» и «образовательное проектирование». С точки зрения И.А. Колесниковой и М.П. Горчаковой-Сибирской понятие «педагогическое проектирование» объединяет «все виды проектной деятельности, субъектом которой может выступать педагог. Они осуществляются, - отмечают авторы, - в педагогических целях или их результат имеет педагогические последствия〉 (Колесникова, 2007: 36).

В последние годы в педагогической литературе и в нормативных документах в качестве аналога термина «педагогическое проектирование» используется понятие «педагогическая деятельность по проектированию». Например, в профессиональ- 
ном образовательном стандарте педагога оно используется в контексте реализации таких функций педагогического работника, как разработка программно-методического и научно-методического обеспечения реализации программ, отдельных курсов, дисциплин (модулей), отдельных видов учебных занятий и т.д., а так же как организация проектной деятельности обучающихся.

В настоящее время общая теория проектирования разрабатывается в общей педагогике, а в педагогике профессионального образования предметом исследования является специфика теоретического и практико-ориентированного знания о проектной деятельности. При этом преобладающей становится трактовка проектирования как процесса разработки проекта, а под проектной деятельностью понимается его полный жизненный цикл от начала до планового завершения или досрочного прекращения. Однако, во многих педагогических работах термины «проектирование» и «проектная деятельность» используются как взаимозаменяемые. Отчасти это делается для того, чтобы избежать многократного повторения в тексте одних и тех же слов или словосочетаний, а также в ситуации, когда нет необходимости в отражении специфики, например, процесса разработки проекта и его реализации.

В последние годы, особенно в педагогике профессионального образования, наметилась тенденция исследования проблемы управления проектами. В соответствии с этим, расширяется терминологический аппарат этой области исследования за счёт его пополнения из двух источников: первый составляет социальное проектирование и управление проектами; второй источник - это понятия, выработанные в педагогической науке.

Из первого источника переносятся в педагогику наиболее распространённые термины, которые соотносятся с образовательным контекстом их употребления. Так, например, по сложившейся в теории социального проектирования и в теории управления проектами традиции жизненный цикл проекта подразделяют на фазы, в состав которых, в свою очередь включаются этапы и /или стадии. Этой традиции следуют С.Я. Батышев, А.Д. Новиков, А.М. Новиков и др. учёные-педагоги.

В отношении количества и наименования стадий и этапов у исследователей нет общей точки зрения. Ряд исследователей, представляющих различные области научного знания (В.Н. Дункан, М.Н. Грашина, В.И. Слободчиков, В.З. Юсупов и др.), не без основания, утверждают, что количество и наименование стадий жизненного цикла проекта, зависят от области или сферы деятельности, в которой он разрабатывается и реализуется.

В системе государственного управлении проектами в образовании принято, руководствуясь Постановлением Правительства Российской Федерации от 15 октября 2016 г., № 1050 «Об организации проектной деятельности в Правительстве Российской Федерации», выделять четыре этапа жизненного цикла проекта: инициирование, подготовка, реализация и завершение. При этом первые два этапа включаются в состав стадии разработки проекта, а два другие образуют стадию реализации проекта. Можно предположить, что этой же логикой руководствовались разработчики 
новых ФГОС ВО, обозначаемые как 3++, в которых одна из категорий (групп) универсальных компетенций имеет наименование «Разработка и реализация проектов».

На формирование в педагогике современных смыслов понятия «проект» наиболее существенное влияние оказывают его трактовки в стандартах по теории управления проектами, в которых выделены такие характерные черты проектной деятельности, как её универсальность, (технологичность) нормированность, специфическая организационная форма, ограниченность определённым промежутком времени и ресурсами, уникальность получаемых продуктов, услуг, результатов.

Понятие результат в проектной деятельности чаще всего применяется как более общее, чем продукт или услуга для обозначения того, что получено в итоге осуществления проекта, его полезный эффект. Слово «результат» в области образования преимущественно используется в значении результат образования (образовательный результат), имея в виду развитие совокупности мотивационных, когнитивных, операционных и других возможностей личности. Например, в педагогике профессионального образования идёт речь о результатах освоения образовательных программ, в качестве которых выступает совокупность сформированных компетенций. Каждая компетенция представляет собой способность выпускника на основе освоенных знаний, умений, навыков, сформированных личностных качеств решать задачи профессиональной деятельности.

«Продукт» в теории управления проектами - понятие более узкое, чем результат. Или рассматривается как «разновидность» результата - «овеществлённый», поддающийся измерению. В социальном проектирования, с точки зрения В.А. Лукова, разработанное социальное нововведение может быть представлено в форме нового предмета или вещи, а так же их новых свойств, новой услуги, новых организаций или их структурных подразделений, мероприятий, проводимых с применением характерных для социального проектирования подходов, невещественных свойств и отношений (например, новые каналы коммуникаций) (Луков, 2003: 37-48). В педагогике профессионального образования к числу продуктов проектной деятельности педагога можно отнести образовательную программу или её отдельные компоненты (например, учебный план), образовательные технологии и т.д. Их составление чаще всего завершает стадию разработки педагогического проекта, но может выступать и в качестве итога всего жизненного цикла проектной деятельности (например, в ситуации апробации новых образовательных программ или новых дидактических средств обучения).

Существуют многочисленные классификации проектов: общие и по отдельным областям проектной деятельности, по различным основаниям. Наиболее целесообразной с точки зрения автора настоящей статьи, является классификация, выделяющая три типа проектов в образовании: педагогические, образовательные и учебные.

Педагогический проект - это предварительно разработанное содержание и совокупность условий эффективной организации педагогом образовательной деятельности обучающихся, которые, будучи реализованными на практике, должны обе- 
спечить достижение за определённый промежуток времени должных результатов образования.

Разработка такого проекта рассматривается одними исследователями, как этап педагогической деятельности, другими - как её вид: в профессиональных стандартах - как функция деятельности педагога. Вместе с тем, педагогический проект, как и любой другой, может выступать в качестве способа осуществления изменений в содержании, организации, условиях осуществления педагогической деятельности. Таким образом, педагогический проект можно рассматривать в различных контекстах: как этап, вид, функцию, способ разработки и осуществления инновационных изменений в профессиональной деятельности и в целом - в образовательной организации.

В трактовке понятия «образовательный проект» должны быть представлены, с одной стороны общие, присущие всем проектам сущностные черты, а с другой его специфика в сфере образования. В этой связи правомерно следующее определение: образовательный проект - это комплекс взаимосвязанных мероприятий, имеющих общую форму организации целенаправленной деятельности для достижения в условиях ограниченного промежутка времени и ресурсного обеспечения нового образовательного продукта, услуги, результата.

Третий вид проектов в высшей школе является результатом учебного проектирования. Это учебные, курсовые, дипломные проекты, проекты в области профессиональной деятельности будущего специалиста.

В.3. Юсупов и С.В. Капин отмечают возрастание роли проектной деятельности в образовании, поскольку она «представляет собой универсальный способ постановки и решения проблем, который может быть широко использован в проектировании практически всех объектов сферы образования» (Юсупов, 2017: 17). В настоящее время, считают исследователи, приоритетное значение имеет теоретическое обоснование и разработка технологии формирования универсальной компетенции, получившей название «Разработка и реализация проектов». Она является «единой по уровням образования для всех направлений и специальностей» (Юсупов, 2019: 350).

Таким образом, теоретический анализ идей проектной деятельности в образовании убедительно показывает, что их развитие осуществляется на основе концепций сформированных в педагогической науке конца XIX - начала XX в., а так же теории социального проектирования и управления проектами. Возрастание роли проектной деятельности в настоящее время актуализирует проблему её использования как универсального способа постановки и решения актуальных задач современной образовательной организации.

\section{СПИСОК ЛИТЕРАТУРЫ}

Колесникова, И.А., Горчакова-Сибирская, М.П. (2007) Педагогическое проектирование: учеб. пособие для высш. учеб. заведений; под ред. И.А. Колесниковой. 2-е изд., стер. М.: Издательский центр «Академия». 288 с. 
Краевский, В.В. (1994) Методология педагогического исследования: учеб. пособие для курсов повыш. квалиф. науч.-пед. кадров. - Самара: СамГПИ. 165 с.

Луков, В.А. (2003) Социальное проектирование: учеб. пособие. 3-е изд., перераб. и доп. М. : МГСА (МосГУ). 240 с.

Сидоренко, В.Ф. (1985) Генезис проектной культуры // Вопросы философии. № 10. С. 87-99.

Слободчиков, В.И. (1996) Основы проектирования развивающего образования // Модель гимназии как инновационного образовательного учреждения: м-лы науч.-практ. конф. - М.: ИПИ РАО. С. 16-24.

Юсупов, В.3., Капин, С.В. (2017) Анализ понятий «проект» и «проектирование» в педагогике: генезис, сущность, классификация // Актуальные проблемы современного образования / Национальная научная конференция, МосГУ. [Электронный ресурс]: Доклады и материалы / под ред. В.А. Ситарова, В.З. Юсупова. М.: МосГУ. URL: https://mosgu.ru/nauchnaya/publications/2017/proceedings/Issues-Contemporary-Education.pdf (Дата обращения: 23.07.2020.).

Юсупов, В.З., Капин, С.В. (2019) Универсализация проектной компетенции будущего педагога на основе междисциплинарного подхода // II-е Моисеевские чтения: Культура как фактор национальной безопасности: доклады и материалы Общероссийской (национальной) научной конференции. Москва, 26 июня 2019 г. / под ред. А.В. Костиной, В.А. Лукова. - М.: МосГУ, 2019. - 517 с. - С. 346-355.

Башкирова Людмила Ивановна - заместитель директора Западнодвинского технологического колледжа им. И.А. Ковалёва. Аспирант кафедры педагогики и психологии высшей школы Московского гуманитарного университета. Научный руководитель - д.п.н., проф. Юсупов В.3. Адрес: 172611, Россия, Тверская область, Западнодвинский район, г. Западная Двина, улица Мира, 12. Эл. адрес: kolledg-zdv@ yandex.ru

Bashkirova Lyudmila Ivanovna - Deputy Director of the Zapadnodvinsk technological College named after I.A. Kovalev, post-graduate student of the Department of pedagogy and psychology of the higher school of the Moscow humanitarian University. Scientific supervisor-doctor of science, prof. Yusupov V. Z. Postal address: 12 Mira street, Tver region, 172611, Russian Federation. E-mail: kolledg-zdv@yandex.ru

\section{Для цитирования:}

Башкирова Л.И. Развитие идей проектирования как способа инновационных изменений в образовательной организации // Научные труды Московского гуманитарного университета. 2020. №4. C. 28-34. DOI: https://www.doi.org/10.17805/trudy.2020.4.4 